International Journal of Business Management and Economic Review

Vol. 4, No. 02; 2021

ISSN: 2581-4664

\title{
THE ROLE OF ORGANIZATIONAL COMMITMENT IN MEDIATING THE EFFECT OF JOB CHARACTERISTICS AND ORGANIZATIONAL SUPPORT ON EMPLOYEE LOYALTY OFMUHAMMADIYAH ACEH UNIVERSITY
}

\author{
*Mukhtaruddin, Muhammad Adam, T. Meldi Kesuma \\ Department of Management, UniversitasSyiah Kuala, Indonesia \\ http://doi.org/10.35409/IJBMER.2021.3243
}

\begin{abstract}
This study intends to examine the role of organizational commitment to mediate the effect of job characteristics and organizational support on employee loyalty at the University of Muhammadiyah Aceh (Unmuha). The study population comprised all 193 Unmuha employees. Unmuha employees are structural lecturers and educational staffswho are scattered in each work unit. Data were analyzed by Structural Equation Modeling (SEM). The direct test results found that job characteristics and organizational support significantly affect organizational commitment; job characteristics, organizational support and organizational commitment significantly affect employee loyalty; and the indirect test result found that organizational commitment mediates the effect of job characteristics and organizational support on employee loyalty. These findings reinforce the notion that the model of increasing employee loyalty, especially in Unmuha, is strongly influenced by job characteristics and organizational support, supported by an organizational commitment that acts as a partial mediator. Further researchers can develop this proven model by adding new variables such as organizational culture and talent management to further complement the employee loyalty model.
\end{abstract}

Keyword: Organizational Commitment, Job Characteristics, Organizational Support, Employee Loyalty.

\section{INTRODUCTION}

UniversitasMuhammadiyah Aceh (Unmuha) is one of the private universities in the city of Banda Aceh, Indonesia. Unmuha consists of several faculties, namely the Faculty of Law, the Faculty of Economics, the Faculty of Engineering, the Faculty of Public Health, the Faculty of Psychology, the Faculty of Islam, and the Faculty of Vocational Studies. The high level of competition in the world of education requires Unmuha to always show its best performance. In carrying out its role as a formal institution that carries out the function of improving the quality of Indonesia's human resources through education, employee loyalty is needed.

Employee loyalty affirms that employees are emotionally bound physically, mentally, and emotionally towards achieving organizational goals. Employee loyalty is an attitude manifested by active or passive behavior aimed at supporting the organization is understood as a group of people through performance that goes beyond the call of duty(Lewicka, Glinska-Newes, Morrow, \& Gorka, 2018). The level of employee loyalty to Unmuha is currently still lacking. This is evident from the data on the number of employees currently owned as shown in the 
International Journal of Business Management and Economic Review

Vol. 4, No. 02; 2021

ISSN: 2581-4664

following table

Table 1. The Number of Unmuha Employees

\begin{tabular}{|l|l|l|l|l|}
\hline Year & $\begin{array}{l}\text { Number } \\
\text { of } \\
\text { employees }\end{array}$ & $\begin{array}{l}\text { Number of } \\
\text { Employees } \\
\text { Entering }\end{array}$ & $\begin{array}{l}\text { The number of } \\
\text { employees who } \\
\text { resigned }\end{array}$ & $\begin{array}{l}\text { Percentage of the } \\
\text { number of employees } \\
\text { who resigned }\end{array}$ \\
\hline 2017 & 167 & 40 & 10 & $5.99 \%$ \\
\hline 2018 & 173 & 15 & 9 & $5.20 \%$ \\
\hline 2019 & 178 & 17 & 12 & $6.74 \%$ \\
\hline
\end{tabular}

Source: Unmuha (2020)

Based on table 1 it can be seen that the percentage of Unmuha employees who left their jobs from 2017-2019. During these three years, it can be seen that in 2017, the figure was 5.99\%, 2018 5.20\%, and in 2019 as much as 6.74\%. This shows that employee loyalty fluctuates in employee turnover in that year. Employee turnover at Unmuha reflects the lack of loyalty from employees towards the institution. Many employees who come in and out result in inconsistent duties and responsibilities. Based on the facts that occur and the results of research that has been conducted by previous researchers, it shows that employee loyalty is very important in achieving the goals of an organization where employees with a high level of loyalty will provide more value to the institution where they work so that the institution can be more advanced.

To see the level of loyalty of Unmuha employees, researchers conducted an initial survey of 30 Unmuha employees. The survey results obtained a result of 3.31 on the Likert scale where this figure shows that the level of loyalty possessed by Unmuha employees is still not good. The level of employee loyalty cannot be separated from the organizational commitment possessed by employees. Organizational commitment has a positive and significant effect on employee loyalty, employees who already have organizational commitment will increase their loyalty, the higher the commitment, the higher the loyalty, the organization must be responsible for its employees so that employees will feel ownership and care for their organization.

From the results of the initial survey that the researchers conducted regarding the organizational commitment of Unmuha employees, the mean value was 3.35, where on the Likert scale this value indicated that it was in the unfavorable category. The low level of organizational commitment is due to the low level of willingness, trust, sense of belonging, and desire to maintain the membership of Unmuha employees as well as a lack of employee understanding of organizational values, especially in achieving organizational goals.

Factors that affect organizational commitment and impact employee loyalty are job characteristics and organizational support. Based on the above phenomena, the researcher wants to measure how much role the job characteristics and organizational support have in influencing organizational commitment and its impact on employee loyalty at Unmuha and how big the role of organizational commitment in mediating these two variables affects employee loyalty.

\section{LITERATURE STUDY}

Employee Loyalty

(Husni, Musnadi, \& Faisal, 2017)stated that in carrying out employee work activities will 


\section{International Journal of Business Management and Economic Review}

Vol. 4, No. 02; 2021

ISSN: 2581-4664

not be separated from loyalty and work attitude, so that the employee will always do a good job.(Lumiu, Pio, \& Tatimu, 2019)stated that the emergence of job loyalty is influenced by one of the job characteristics factors. Needs in work such as work facilities, welfare benefits, work atmosphere, and wages received from the company. Employee loyalty is influenced by several factors, namely job characteristics, organizational support, and organizational commitment. While(Silvia et al., 2014)expressed loyalty as an attitude is influenced by four factors, namely personal characteristics, job characteristics, company design characteristics, and experience.

In this research, the measurement of employee loyalty uses indicators as disclosed by(Lumiu et al., 2019)namely obedience and obedience, responsibility, devotion, honesty, and accepting mistakes. This indicator was chosen because it fits and fits the research model that the researcher built in this research.

\section{Organizational Commitment}

Employee commitment will not grow by itself, there is a significant relationship between work culture and employee commitment(Rizqina, Adam, \& Chan, 2017).(Greenberg \& Baron, 2018)stated organizational commitment as the degree to which employees are involved in the organization and desire to remain as members, which contains loyalty and willingness of employees to work optimally for the organization where the employee works. While(Mathis \& Jackson, 2019)argued that organizational commitment is the level to which an employee believes and accepts organizational goals and desires to stay with the organization.

Organizational commitment can be measured using indicators as disclosed by(Mahalingam\& Suresh, 2018)namely trust and acceptance, willingness, desire, contributing, and a sense of belonging. This indicator was chosen because it fits the model built in this research.

\section{Job Characteristics}

Job characteristic is expressed as attributes of employee duties and include a number of responsibilities, various tasks, and the extent to which the job has characteristics that can make employees feel satisfied(Tamalero et al., 2012). Job characteristics will reflect work that can give birth to three psychological conditions in employees, namely experiencing the meaning of work, taking responsibility for work results, and knowledge of work results. And these three psychological conditions will affect work motivation, performance, employee turnover, and job loyalty(Wang, Ma, \& Zhang, 2014).

These job characteristics are the nature and duties which include responsibilities, types of tasks, and the level of satisfaction obtained from the work itself(Silvia et al., 2014).Meanwhile(Robbins \& Judge, 2017)mentioned a job characteristic is an approach in designing work that shows how jobs are described into five core dimensions, namely skill diversity, task identity, task meaning, autonomy, and feedback.

(Wang et al., 2014)and(Lewicka et al., 2018)revealed that job characteristics can be measured using the following indicators, namely variations in skills, task identity, task significance, task autonomy, and feedback. This indicator is relevant to the problem and the research model built in this research

\section{Organizational Support}




\section{International Journal of Business Management and Economic Review}

Vol. 4, No. 02; 2021

ISSN: 2581-4664

(Adhika \& Riana, 2016)revealed that organizational support is defined as employees' general beliefs about the extent to which the organization values their contributions and cares about their well-being. If organizational support that is felt is positive and organizational commitment is strong, it is likely to provide high job satisfaction(Robbins \& Judge, 2017). (Danish, Ramzan, \& Ahmad, 2013)stated organizational support as employees' expectations that the organization appreciates the contribution and work that employees do properly.

Organizational support can be measured using indicators as revealed by(Achmad\& Yuniawan, 2018)namely rewards, development, working conditions, employee welfare, and transparency of information. This indicator was chosen because it is relevant to the model developed in this research.

\section{Conceptual framework and Hypothesis}

The conceptual framework and research hypothesis is shown as follows :

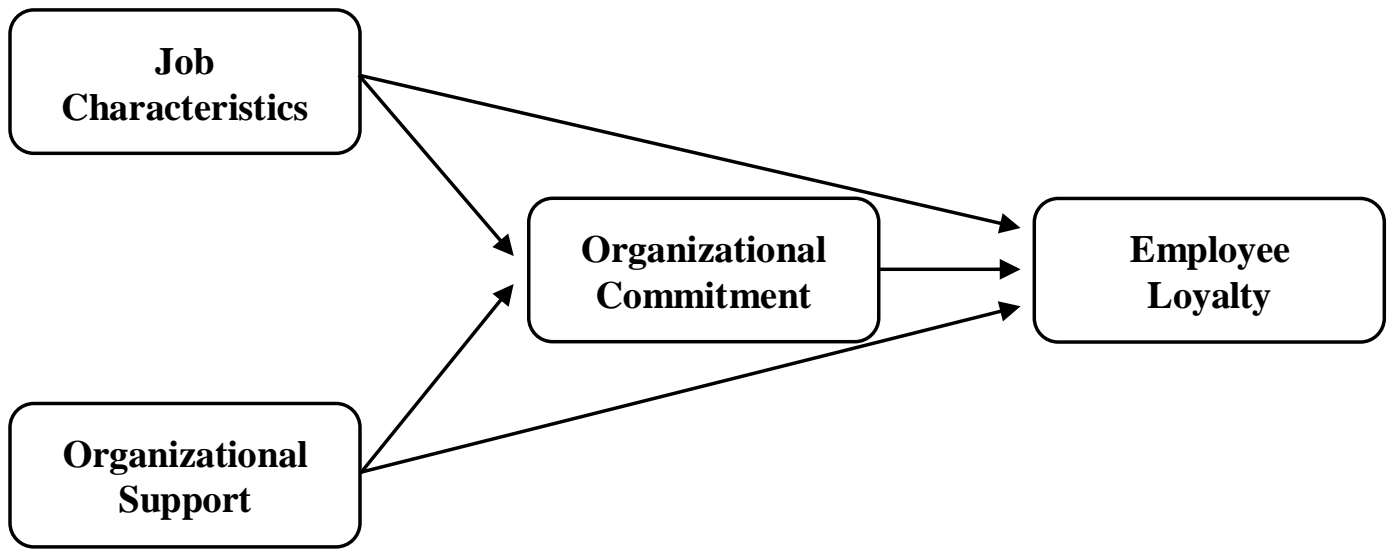

Figure 1.Conceptual Framework

H1 : Job characteristicsignificantlyaffectsUnmuha's organizational commitment

$\mathrm{H} 2$ : Organizational support significantly affects Unmuha's organizational commitment

H3 : Job characteristics significantly affect Unmuha employee loyalty

H4 : Organizational support significantly affects Unmuha employee loyalty

H5 : Organizational commitment significantly affects Unmuha employee loyalty

H6 : Organizational commitment can mediate the effect of job characteristics on Unmuha employee loyalty

H7 : Organizational commitment can mediate the effect of organizational support on Unmuha employee loyalty

\section{RESEARCH METHOD}

This research was conducted at Unmuha with the object of research with the number of respondents as many as 193 people where the respondents were all structural educators and educational staff at Unmuha who were scattered in each work unit. Data were collected using a questionnaire and measured using a Likert scale. Data were analyzed using Structural Equation 
International Journal of Business Management and Economic Review

Vol. 4, No. 02; 2021

ISSN: 2581-4664

Modeling (SEM). The specifications of the research model in the series of equations are as follows:

Organizational Commitment $=$ Job Characteristics + Organizational Support $+\zeta 1$

Employee Loyalty $=$ Job Characteristics + Organizational Support + Organizational Commitment $+\zeta 2$

Mathematically, the research model can be stated as follows:

$\eta=\gamma 1.1 \xi 1+\gamma 1.2 \xi 2+\zeta 1$

$\eta=\gamma 1.1 \xi 1+\gamma 1.2 \xi 2+\beta 21 \eta 2+\zeta 2$

or

Organizational Commitment $=\gamma 11$ Job Characteristics $+\gamma 12$ Organizational Support $+\zeta 1$

Employee Loyalty $=\gamma 21$ Job Characteristics $+\gamma 12$ Organizational Support $+\beta 21$ Organizational Commitment $+\zeta 2$

Hypothesis testing is done in 2 (two) ways, namely testing the direct effect and testing the indirect effect with organizational commitment as the mediator variable. The concept of indirect effects testing uses a model developed by(Baron \& Kenny, 1986), by using the Sobel calculator.

\section{RESULT AND DISCUSSION} Direct Hypothesis

The structural model analysis that explains the effect test between variables is presented in the following path diagram:

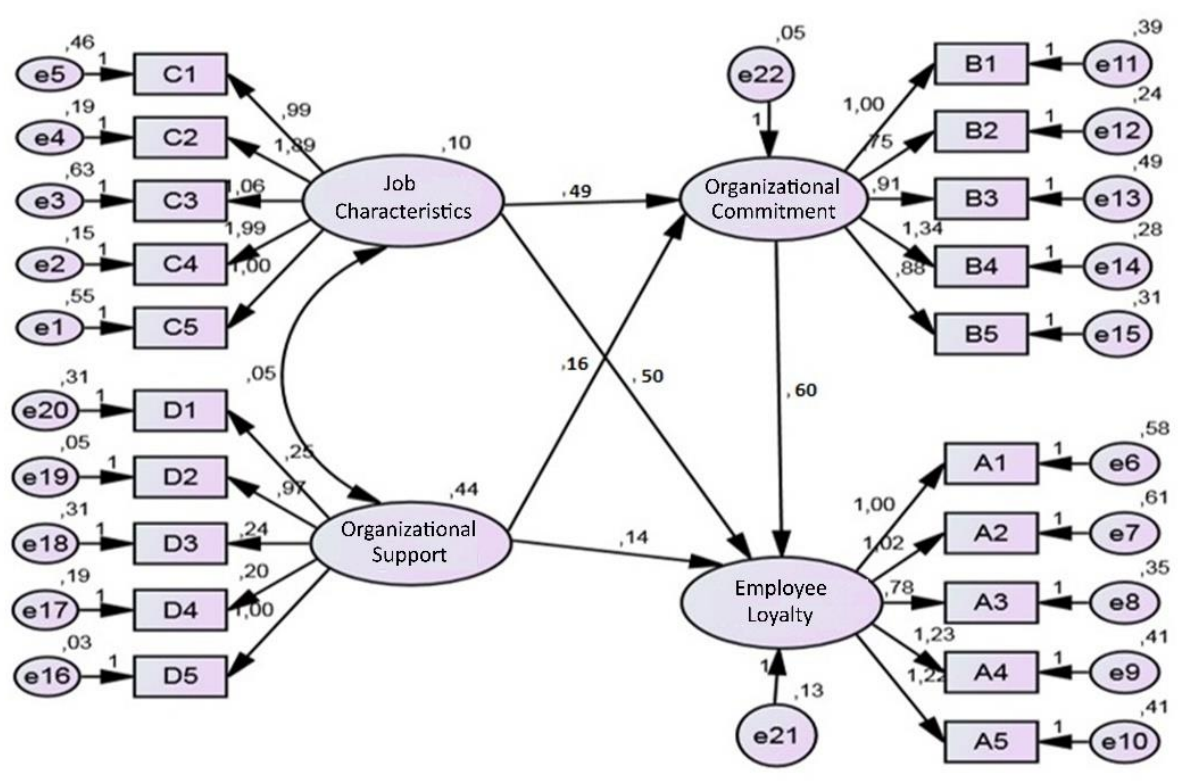

Figure 2.Test Result

The test results of the full model for testing the direct effect hypothesis after fulfilling the SEM assumptions are more clearly shown in the following table: 
International Journal of Business Management and Economic Review

Vol. 4, No. 02; 2021

ISSN: 2581-4664

Table 2. Hypothesis Test Result

\begin{tabular}{|c|c|c|c|c|c|c|}
\hline & & & Estimate & S.E. & C.R. & $\mathrm{P}$ \\
\hline $\begin{array}{l}\text { Organizational_ } \\
\text { Commitment }\end{array}$ & $<---$ & Job_Characteristics & 0.492 & 0.214 & 2.297 & 0.022 \\
\hline $\begin{array}{l}\text { Organizational_- } \\
\text { Commitment }\end{array}$ & $<---$ & Organization_Support & 0.169 & 0.061 & 2.771 & 0.005 \\
\hline Employee_Loyalty & $<---$ & $\begin{array}{l}\text { Organizational_ } \\
\text { Commitment }\end{array}$ & 0.602 & 0.093 & 6.468 & 0.000 \\
\hline Employee_Loyalty & $<---$ & Organization_Support & 0.144 & 0.062 & 2.324 & 0.020 \\
\hline Employee_Loyalty & $<---$ & Job_Characteristics & 0.501 & 0.198 & 2.523 & 0.012 \\
\hline
\end{tabular}

Source: Primary data, 2020 (processed)

Based on the results of SEM analysis in Table 2 and statistical equations (1) and (2), the following results can be formulated:

Organizational Commitment $=0.492$ Job Characteristics +0.169 Organizational Support

Employee Loyalty $\quad=0.501$ Job Characteristics +0.144 Organizational Support +0.602

Organizational Commitment

From the test findings in Table 2, it can be explained as follows:

1. H1: The results of testing hypothesis 1 show that the CR value of job characteristics on organizational commitment is 2.297 with a significant level of 0.022 . The result showsthat the significant value is smaller than the significant level $(0.022<0.05)$, therefore Hol is rejected and $\mathrm{Hal}$ is accepted. This means that job characteristics significantly affect organizational commitment. The magnitude of the influence of job characteristics on organizational commitment is 0.492 or $49.2 \%$. It also explains that the better job characteristics will have a positive and real impact on increasing organizational commitment. Unmuha arranges and arranges work assignments that meet organizational needs, will make employees know their workflow. By knowing the work to be done, employees will feel more concentrated on the job. The better the job description by Unmuha management, the more focused the employees will be in completing the work. So that employees feel happy and comfortable having been able to complete the job. Furthermore, employees will feel a sense of commitment to the organization which is shown by doing their job seriously(Tamalero et al., 2012). Thus it can be said the opposite, the worse the job characteristics, the lower the employee's organizational commitment. These results are in line with the results of research conducted by(Wang et al., 2014), (Konya, Matic, \& Pavlovic, 2016), and(Sancaya, 2018).

2. H2: The result of hypothesis testing 2 shows that the CR value of organizational support on organizational commitment is 2.771 with a significant level of 0.005 . The result showsthat the significant value is smaller than the significant level $(0.005<0.05)$, therefore Ho1 is rejected and Hal is accepted. This means that organizational support significantly affects organizational commitment. The magnitude of the influence of organizational support on 
International Journal of Business Management and Economic Review

Vol. 4, No. 02; 2021

ISSN: 2581-4664

organizational commitment is 0.169 or $16.9 \%$. It also explains that the higher the level of organizational support, the greater the organizational commitment. The influence of Unmuha's support can be reflected in the roles assigned to its employees. Unmuha's support will be felt by employees, so employees think that they are fully supported by the organization in order to complete their work. Employees will contribute more to the organization by being fully committed to the organization. These results are relevant(Gündüz, 2014),(Fakhrae, Amani, \& Manoochehri, 2015), (Adhika \& Riana, 2016)and(Fahrizal\& Utama, 2017)which stated that organizational support can encourage employees to complete their duties. This means that employees feel enthusiastic about completing their work because they feel that they have been helped by the organization where they work. The impact of this spirit is that employees can quickly get work done. $\mathrm{He}$ also feels that he has completed his job effectively and efficiently. So that he will feel fully committed to the organization because he is comfortable working in the organization.

3. H3: The results of hypothesis testing 3 show that the $\mathrm{CR}$ value of job characteristics on employee loyalty is 2.523 with a significant level of 0.012 . The result showsthat the significant value is smaller than the significant level $(0.012<0.05)$, therefore Ho1 is rejected and Ha1 is accepted. This means that job characteristics significantly affect employee loyalty. The estimated value of job characteristics is 0.501 or $50.1 \%$ on employee loyalty. It also explains that the higher the level of job characteristics, the higher employee loyalty. In an organization, the existence of work is composed of job characteristics, whose purpose is to organize work assignments that meet the needs of the organization (Indrasari, 2017:27). The assignment arrangement will be able to provide details of the work to be carried out so that the employee knows which job he has to do. With employees knowing which work they have to do, it will clarify their work, so that employees are not confused and can focus more on completing it. With the clear characteristics of the job given, it will create a feeling of pleasure at work. This feeling will encourage Unmuha employee loyalty to their work. These results are relevant to those disclosed by(Lewicka et al., 2018)that, job characteristics are the basis for the productivity of an organization so that job loyalty is maintained. This encourages employee creativity(Rusu\& Avasilcai, 2014), (Lewicka et al., 2018).

4. H4: The result of hypothesis testing 4 shows that the $\mathrm{CR}$ value of organizational support on employee loyalty is 2.324 with a significant level of 0.020 . The result shows that the significant value is smaller than the significant level $(0.020<0.05)$, therefore Hol is rejected and Ha1 is accepted. This means that organizational support significantly affects employee loyalty. The magnitude of the influence of organizational support on employee loyalty is 0.144 or $14.4 \%$. It also explains that the higher the level of organizational support, the more employee loyalty will be. The support provided by Unmuha to employees means that the organization fully supports the implementation of employee activity processes and gives good trust to its employees. With that, employees consider themselves valued by the organization where they work and in the long run will create loyal employee attitudes. Loyal Unmuha employees tend to facilitate the company in carrying out its strategy and produce useful results. These conditions make employees feel like contributing more to Unmuha. This contribution is realized by employees with an attitude of loyalty to the organization. The impact of this perception is that employees will do better for the 
Vol. 4, No. 02; 2021

ISSN: 2581-4664

organization. Employees will be willing to work and sacrifice earnestly, even willing to work outside their working hours. These results are relevant(Achmad\& Yuniawan, 2018), revealed that organizational support is a very important component for creating employee loyalty. This means that with organizational support, employees will feel happy because they are helped in completing their work. This is in the employee's perception that he feels valued by the organization because he gets support from the organization to complete his work effectively and efficiently(Tariq, Ilyas, \& Rehman, 2017). The impact of this perception is that employees will do better for the organization. Employees will be willing to work and sacrifice earnestly, even willing to work outside their working hours.

5. H5: The results of hypothesis 5 testing show that the $\mathrm{CR}$ value of organizational commitment to employee loyalty is 6.468 with a significant level of 0.000 . The result shows that the significant value is smaller than the significant level $(0.000<0.05)$, therefore Ho1 is rejected and Hal is accepted. This means that organizational commitment significantly affects employee loyalty. The estimated value of organizational commitment to employee loyalty is 0.602 or $60.2 \%$. It also explains that the higher the organizational commitment, it will have a direct effect on increasing employee loyalty. Unmuha employees who already have a sense of commitment to their organization will not hesitate to do more for their organization. Organizational commitment is multidimensional and involves employee loyalty to the organization. Employee loyalty cannot be determined through direct questions, no one can assume whether Unmuha employees are currently working effectively. Loyalty and commitment are more of simple behaviors - they are all like customer loyalty and commitment(Mahalingam\& Suresh, 2018). Employees and organizations have reciprocal responsibilities and mutual commitments both that express and define their relationship. Sometimes managers persuade employees to adopt new strategies that it is unrealistic for managers to have high expectations for their employees(Iqbal, Tufail, \& Lodhi, 2015). These results are relevant(Pandey\& Khare, 2012), (Iqbal et al., 2015)and(Ajimat, 2019).They stated that organizational commitment is the attitude that exists in the soul of employees that reflects care and loyalty to the organization and its continued success and well-being, meaning that employees who already have a sense of loyalty to their organization will feel that they belong to the organization.

\section{Indirect Hypothesis (Mediation)}

The results of testing the indirect hypothesis (mediation) are described below:

1. H6: the role of mediation Organizational commitment to the effect of job characteristics on employee loyalty Unmuha as can be seen in the following figure: 


\section{International Journal of Business Management and Economic Review}

Vol. 4, No. 02; 2021

ISSN: 2581-4664

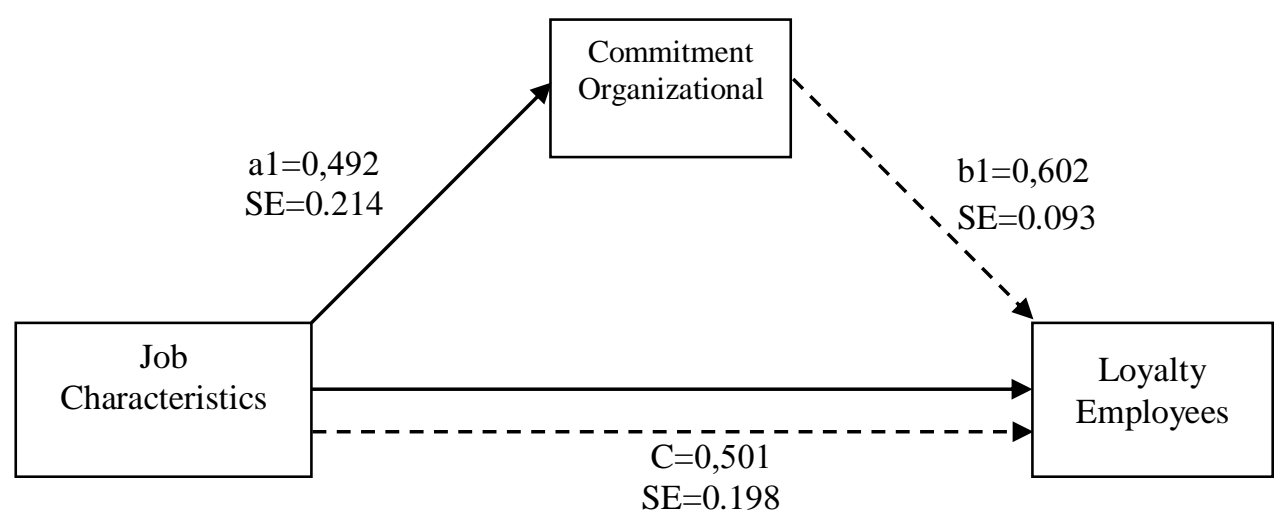

Figure 3.Result of Hypothesis 6 (Mediation Effect)

Based on Figure 3 above, the model forms a path (path analysis) with the organizational commitment variable as a mediator. The $\mathrm{z}$ value is generated from the results of calculations using the Sobel test as follows.

$\mathrm{Z}_{1}=\frac{a 1 b 1}{\sqrt{\left(b 1^{2} S E a 1^{2}\right)+\left(a 1^{2} S E b 1^{2}\right)}}$

$$
Z=2,1664
$$

From the above calculation, the $\mathrm{z}$ value is $2.1664>1.96$ with a significance level of 0.030 $<0.05$. These results indicate that there is an indirect influence between job characteristics on employee loyalty mediated by fully mediated organizational commitment. So it can be stated that the hypothesis Ha6 is accepted, namely, organizational commitment mediates the effect of job characteristics on employee loyalty at Unmuha.

This indirect influence can be seen from the role of job characteristics that will make employees have the organizational commitment so that they will be loyal to Unmuha. Unmuha employees who have good job characteristics will focus on the basis for organizational productivity so that work loyalty is maintained. In conditions of increasing competition, a well-designed job will be able to attract and maintain workforce loyalty and provide motivation to produce quality products and services. (Lewicka et al., 2018). Employees have job characteristics that vary in skills, task identity, task significance, autonomy, and feedback. The variety of skills includes different job activities that require incumbents to have a variety of talents and abilities to get the job done. This means that employees can do the job wholeheartedly. This condition will foster employee loyalty to their work. The impact of job characteristics will make employees feel loyal to their organization. This must be through the organizational commitment that grows in it.

This result is in agreement with(Rusu\& Avasilcai, 2014)and(Lewicka et al., 2018)in their research found that job characteristics have a positive effect on employee loyalty through organizational commitment. This shows that the better the job characteristics in an 
Vol. 4, No. 02; 2021

ISSN: 2581-4664

organization, the more employee loyalty will be if there is organizational commitment. Thus it can be said the opposite, if the lower the job characteristics, the lower employee loyalty through organizational commitment

2. H7: the influence of organizational support on Unmuha employee loyalty through organizational commitment as shown in the following picture. 3.

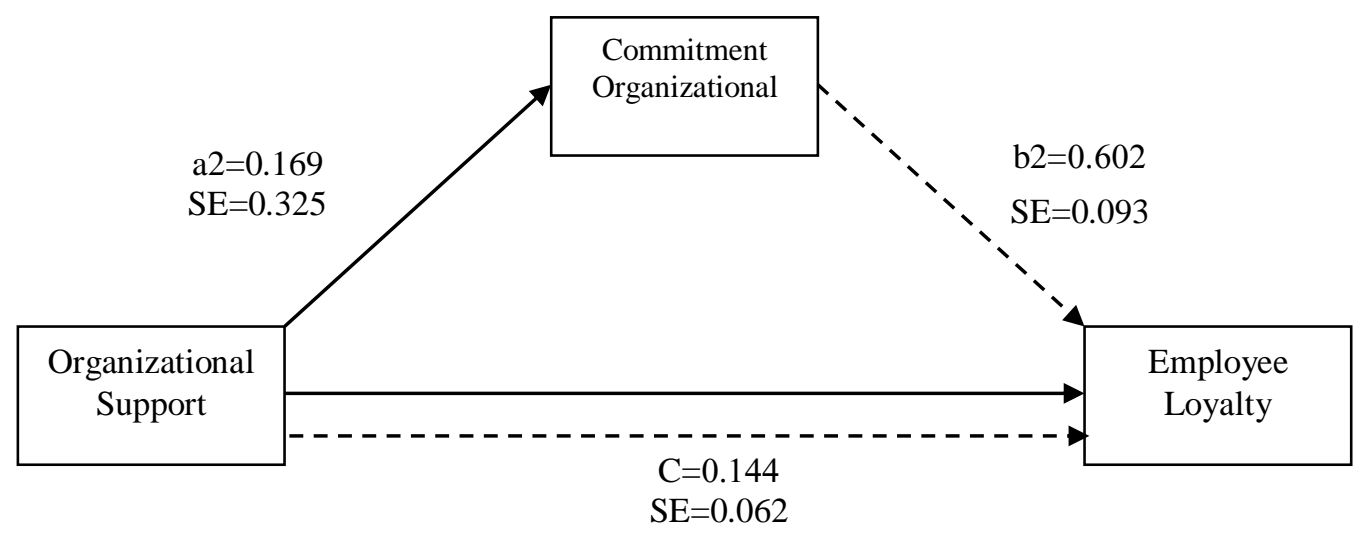

Figure 4.Result of Hypothesis 7 (Mediation Effect)

Based on Figure 4 above, the model forms a path (path analysis) with the organizational commitment variable as a mediator. The $\mathrm{z}$ value is generated from the results of calculations using the Sobel test as follows.

$\mathrm{Z}_{1}=\frac{a 1 b 1}{\sqrt{\left(b 1^{2} S E a 1^{2}\right)+\left(a 1^{2} S E b 1^{2}\right)}}$

$$
Z=2,5470
$$

From the above calculation, the $\mathrm{z}$ value is $2.5470>1.96$ with a significance level of 0.010 $<0.05$. These results indicate that there is an indirect influence between organizational support on employee loyalty mediated by organizational commitment in a partial mediation. Thus it can be stated that the hypothesis Ha7 is accepted, namely, organizational commitment mediates the effect of organizational support on Unmuha employee loyalty.

This can be seen from the role of Unmuha's support for employee loyalty through organizational commitment. Unmuha employees who feel supported by their organization will be fully loyal to their organization. This is because employees feel employees' confidence about how far the organization they work for appreciates contributions and cares about their welfare. With the growing sense of loyalty, that the increase in employee loyalty can be caused by the social relationships made by each individual, then employees will ultimately be fully committed to their organization and to what extent their 


\section{International Journal of Business Management and Economic Review}

Vol. 4, No. 02; 2021

ISSN: 2581-4664

organization assesses contributions and pays attention to employees' lives(Achmad\& Yuniawan, 2018).

(Tariq et al., 2017), (Iqbal et al., 2015), (Achmad \& Yuniawan, 2018)revealed that employees will increase their loyalty when they feel the support provided by the organization. However, this condition will occur if employees have grown organizational commitment to their organization(Tariq et al., 2017). This shows that the greater the organizational support to its employees, the greater the loyalty in the soul of the employee, but must go through the existing organizational commitment of the employee. Vice versa, the lack of organizational support provided to employees, the employee loyalty will also decrease but must go through a growing commitment to the employee.

\section{CONCLUSION}

The direct test results found that job characteristics and organizational support significantly influence organizational commitment; job characteristics, organizational support and organizational commitment significantly affect employee loyalty; and the indirect test results found that organizational commitment mediates the effect of job characteristics and organizational support on employee loyalty. These findings reinforce the notion that the model of increasing employee loyalty, especially in Unmuha, is strongly influenced by job characteristics and organizational support, supported by an organizational commitment that acts as a partial mediator. Further researchers can develop this proven model by adding new variables such as organizational culture and talent management to further complement the employee loyalty model.

The findings of this research can also be a reference for practitioners, especially at Unmuha as research objects. In the employee loyalty variable, the lowest average value is on the indicator of accepting errors. This fact proves that in the realization of their loyalty, employees are still not fully wise in accepting mistakes and not blaming colleagues. This requires the ability of Unmuha leaders to analyze problems when they occur, to be wise in understanding, and fair in making decisions so that they can avoid unwanted things.

In the organizational commitment variable, there is one indicator that has the lowest value, namely the contribution in every activity organized by the organization. This is a task that must be resolved by the leadership of the organization to create high organizational commitment and synergize with each other by prioritizing solidity in it so that every Unmuha employee feels his presence in the organization where he works. Job characteristics have one of the indicators with the lowest score than the others, namely feedback. When employees are competing in giving their best contribution, organizations tend not to provide feedback with job promotions so that their loyalty will be better for the progress of Unmuha.

Furthermore, information transparency is the indicator with the lowest score for the organizational support variable. Thus, it is hoped that Unmuha will always deliver information transparently in the future, both related to rewards and punishments. This can create a high level of trust in the organization, which in turn will increase employee loyalty.

\section{REFERENCES}

Achmad, A. W., \& Yuniawan, A. (2018). Analisis Efek Dukungan Sosial, Budaya Organisasi, Dan Kohesivitas Karyawan Terhadap Loyalitas Karyawan (Studi pada RS. Aisyiyah Kudus). 


\section{International Journal of Business Management and Economic Review}

Vol. 4, No. 02; 2021

ISSN: 2581-4664

Diponegoro Journal of Management, 7(4), 1-13. $\quad$ Retrieved from
https://ejournal3.undip.ac.id/index.php/djom/article/view/22327

Adhika, I. N. R., \& Riana, I. G. (2016). Pengaruh Dukungan Organisasional Dan Kepuasan Kerja Terhadap Komitmen Organisasional (Studi Pada Koperasi Simpan Pinjam Di Denpasar Utara). E-Jurnal Ekonomi Dan Bisnis Universitas Udayana,5(4), 857-876. Retrieved from https://ojs.unud.ac.id/index.php/EEB/article/view/12332

Ajimat. (2019). Peran Komitmen Organisasi Dalam Pengaruh Negatif Turnover Intention Terhadap Loyalitas Karyawan (Studi Kasus di Universitas Pamulang). Jurnal Ekonomi Efektif, 2(1), 94-100. https://doi.org/http://dx.doi.org/10.32493/JEE.v2i1.3506

Baron, R. M., \& Kenny, D. A. (1986). The moderator-mediator variable distinction in social psychological research: Conceptual, strategic, and statistical considerations. Journal of Personality and Social Psychology, 51(6), 1173.

Danish, R. Q., Ramzan, S., \& Ahmad, F. (2013). Effect of Perceived Organizational Support and Work Environment on Organizational Commitment; Mediating Role of Self-Monitoring. Advances in Economics and Business, 1(4), 312-317. https://doi.org/10.13189/aeb.2013.010402

Fahrizal, \& Utama, I. W. M. (2017). The Influence of Organizational Support Perception on Organizational Commitment and Turnover Intention of Kajane Hotel Employees, MUA UBUD. E-Jurnal Manajemen Unud, 6(10), 5405-5431.

Fakhrae, M., Amani, R., \& Manoochehri, S. (2015). Effects of Organizational Support on Organizational Commitment. Management and Administrative Sciences Review, 4(5), 766-771.

Greenberg, J., \& Baron, R. A. (2018). Behavior in Organizations: Understanding and Managing the Human Side of Work (Ed. 8). New Jersey: Prentice Hall.

Gündüz, Y. (2014). The Effect of Organizational Support on Organizational Commitment. Anthropologist, 18(3), 1041-1057. https://doi.org/10.1080/09720073.2014.11891587

Husni, Musnadi, S., \& Faisal. (2017). Pengaruh Lingkungan Kerja, Kompensasi Dan Motivasi Terhadap Kepuasan Kerja Serta Dampaknya Terhadap Loyalitas Kerja Pegawai Rutan Di Provinsi Aceh (Studi Kasus Pada Rutan Klas IIB Banda Aceh Dan Rutan Klas IIB Jantho). Jurnal Magister Manajemen, 1(1), 1-11.

Iqbal, A., Tufail, M. S., \& Lodhi, R. N. (2015). Employee Loyalty and Organizational Commitment in Pakistani Organizations. Global Journal Of Human Resource Management, $3(1), 1-11$.

Konya, V., Matic, D., \&Pavlovic, J. (2016). The Influence of Demographics, Job Characteristics and Characteristics of Organizations on Employee Commitment. Acta Polytechnica Hungarica, 13(3), 119-138.

Lewicka, D., Glinska-Newes, A., Morrow, D. L., \& Gorka, J. (2018). The effect of job characteristics on employee loyalty: the mediation role of vertical trust and perceived supervisory support. Marketing and Management of Innovations, 2, 168-185. https://doi.org/10.21272/mmi.2018.2-14 


\section{International Journal of Business Management and Economic Review}

Vol. 4, No. 02; 2021

ISSN: 2581-4664

Lumiu, C. A., Pio, R. J., \& Tatimu, V. (2019). Pengaruh Karakteristik Pekerjaan, Pengembangan Karir Dan Kompensasi Terhadap Loyalitas karyawan. Jurnal Administrasi Bisnis, 9(3), 93-100.

Mahalingam, S., \& Suresh, M. (2018). The Impact of Organizational Commitment on Employee Loyalty in IT Industry with Reference to Coimbatore City. International Journal of Research in Engineering, Science and Management, 1(5), 55-59.

Mathis, R. L., \& Jackson, J. H. (2019). Human Resource Management: Personnel Human Resource Management (Ed. 15). USA: Harvard Business Review.

Pandey, C., \& Khare, R. (2012). Impact Of Job Satisfaction And Organizational Commitment On Employee Loyalty. International Journal of Social Science \& Interdisciplinary Research, $1(8), 26-41$.

Rizqina, Z. A., Adam, M., \& Chan, S. (2017). Pengaruh Budaya Kerja, Kemampuan, danKomitmen Kerja Terhadap Kepuasan Kerja Pegawai serta Dampaknya Terhadap Kinerja Badan Pengusahaan Kawasan Perdagangan Bebas dan Pelabuhan Bebas Sabang (BPKS). Jurnal Magister Manajemen, 1(1), 59-69.

Robbins, S. P., \& Judge, T. A. (2017). Essential of Organisational Behaviour (14th ed.). New Jersey: Pearson.

Rusu, G., \& Avasilcai, S. (2014). Linking human resources motivation to organizational climate. Procedia - Social and Behavioral Sciences, 124, 51-58. https://doi.org/10.1016/j.sbspro.2014.02.459

Sancaya, I. G. N. W. (2018). Pengaruh Karakteristik Pribadi dan Karakteristik Pekerjaan terhadap Komitmen Organisasi Pengusaha Kain Tenun Endek dalam Pelangi Sidemen Tenun Tradisional pada 2016. Jurnal Pendidikan Ekonomi Undiksha, 10(2). https://doi.org/http://dx.doi.org/10.23887/jjpe.v10i2.20092

Silvia, Rudi, A., \& Miranda, L. (2014). Pengaruh Kompensasi dan Karakteristik Pekerjaan terhadap Loyalitas Karyawan, Studi Kasus di Toko Buku Gramedia Pangkalpinang. Jurnal Progresif Manajemen Bisnis, 1(1).

Tamalero, Y., Swasto, B., \& Hamid, D. (2012). Pengaruh Karakteristik Pekerjaan Dan Kepuasan Kerja Terhadap Komitmen Organisasi Dan Intention To Quit (Studi pada Karyawan PT. Manado Media Grafika). Profit: Jurnal Administrasi Bisnis, 6(2), 23-31.

Tariq, H., Ilyas, M., \& Rehman, C. A. (2017). Assessing Employee Loyalty through Organizational Attributes in Telecom Sector: An Empirical Evidence. Advances in Social Sciences Research Journal, 4(8), 119-129. https://doi.org/https://doi.org/10.14738/assrj.48.3096

Wang, X., Ma, L., \& Zhang, M. (2014). Transformational leadership and agency workers' organizational commitment: The mediating effect of organizational justice and job characteristics. Social Behavior and Personality An International Journal, 4(1), 25-36. https://doi.org/https://doi.org/10.2224/sbp.2014.42.1.25 